\title{
Beneficiation of Faya Clay for Drilling Mud Production Using Froth Floatation and Jig Gravity Concentration Techniques
}

\author{
${ }^{* 1}$ Oladunni O. Alabi, ${ }^{2}$ Paul N. Dodo and ${ }^{2}$ Peter J. Dodo \\ ${ }^{1}$ Department of Metallurgical and Materials Engineering, Federal University of Technology, Akure, Nigeria \\ ${ }^{2}$ Department of Mineral and Petroleum Resources Engineering, Kaduna Polytechnic, Kaduna, Nigeria \\ aoalabi@futa.edu.ng I dodopaul1991@gmail.com
}

Received: 13-AUG-2021; Reviewed: 12-SEP-2021; Accepted: 19-SEP-2021

http://dx.doi.org/10.46792/fuoyejet.v6i3.681

\begin{abstract}
The comparative study for upgrading Faya clay, in Faya Town of Plateau State, Nigeria to oil and Gas drilling mud grade was carried out. The clay was sourced from three veins A, B, and C. The samples were homogenized, crushed and ground. $5 \mathrm{~kg}$ of the homogenized sample was used for the experiment and laboratory work. Chemical and mineralogical characterization of the clay sample was carried out using; X-ray fluorescence (XRF) and X-ray diffractorneter (XRD). The clay sample was beneficiated using two methods: froth flotation and gravity concentration method (Jigging). The chemical composition of the crude clay revealed that it contains $16.6 \% \mathrm{Al}_{2} \mathrm{O}_{3}, 35.6 \%$ $\mathrm{SiO}_{2}, 0.559 \% \mathrm{~K}_{2} \mathrm{O}, 0.084 \% \mathrm{CaO}, 6.133 \% \mathrm{Fe}_{2} \mathrm{O}_{3}, 0.91 \% \mathrm{TiO}_{2}$ and $38.7 \% \mathrm{BaO}$. The result of $\mathrm{XRD}$ analysis shows that quartz is predominant in the sample with $61.7 \%$ wt quartz $\left(\mathrm{SiO}_{2}\right)$. Other minerals found in the sample include $28.59 \%$ wt of dickite $\left(\mathrm{Al}_{2} \mathrm{Si}_{2} 05(\mathrm{OH})\right)$, $8.89 \%$ wt goethite $\left(\mathrm{Fe} 0\left(\mathrm{OH}_{4}\right)\right.$ and $0.83 \%$ wt muscovite $(\mathrm{KO} .92 \mathrm{NaO} .08)$ (Al.86 FeO.07 TiO.02) (Si.3 O.3 AlO.97) $\mathrm{O}_{10}(\mathrm{OH})_{2}$ at $2 \theta$. Froth flotation method is more efficient for the beneficiation of Faya clay as it improves the $\mathrm{BaO}$ composition of the clay from $38.7 \%$ to $52.2 \%$, with a recovery of $97.2 \%$, an enrichment and ratio of concentration of 1.4 compared with the jigging method, which improved $\mathrm{BaO}$ composition from $38.7 \%$ in the crude clay to $47.5 \%$, with a recovery of $90.96 \%$ and an enrichment ratio of 0.7 ; and ratio of concentration of 0.7 . Froth floatation improved the specific gravity of the clay from 3.3 to 4.31 ; while jigging improved the specific gravity from 3.3 to 4 . 05 . Therefore, froth flotation method is more appropriate for the concentration of Faya clay ahead of jigging method of processing.
\end{abstract}

Keywords- Characterization, Drilling, Faya-clay, Production, Upgrading

\section{INTRODUCTION}

$\mathrm{M}$ inerals vary in composition, resulting from assimilation and differentiation during the earth's formative period. Mineral processing is concern with the addition of value; hence, it is the act of treating crude ores and mineral production in order to separate the valuable minerals from the waste rock. Most of the processes involved in mineral processing are physical (Wills, 2006). Concentration simply means separating the desired minerals from the undesirable minerals (gauge). It involves separation of minerals without a change in their chemical composition, structure or state of aggregation. These processes are becoming increasingly integrated with hydrometallurgy and chemical processing (combined system).

Concentration technique includes; gravity concentration, involving the separation of two or more minerals particles of different specific gravity by their relative movement in response to the force of gravity and one or more other forces (such as the centrifugal forces, magnetic forces, buoyant forces), one of which is resistance to motion. Flotation is a physico-chemical method of concentration utilizing differences in surface properties between valuable minerals and gauge. It is a selective method of concentrating low grade and complex ores. Other concentration techniques are; electrostatic separation, ore sorting and magnetic separation. (Gupta, 2006).

\footnotetext{
${ }^{*}$ Corresponding Author

Section D- MATERIALS/ CHEMICAL ENGINEERING \& RELATED SCIENCES Can be cited as:

Alabi O.O.., Dodo P.N. and Dodo P.J. (2021): Beneficiation of Faya Clay for Drilling Mud Production, Using Froth Floatation and Jig Gravity Concentration Techniques, FUOYE Journal of Engineering and Technology (FUOYEJET), 6(3), 56-60. http://dx.doi.org/10.46792/fuoyejet.v6i3.681
}

The peculiar characteristic of Bentonite clays, thixotropic, swelling and absorption properties, have accounted for their demand for various industrial uses. These properties have been attributed to the type of clay mineral, the nature of exchangeable cation (s) present in the Bentonite and its cations exchangeable capacity (Robertson, 1986). Bentonite continues to be the most widely used material for thickening fresh water base drilling fluid. Wyoming Bentonite is the most commonly available commercial Bentonite for drilling fluid applications. It is principally composed of sodium montmorillonite. This accounts for its high swelling capacity and viscosity compared to other bentonites. The rather high viscosity of sodium montmorillonites had been attributed to high degree of hydration of its particles by the dispersed water medium (Theng, 2002). Reports have also shown that a montmorillonite would have high swelling power if its exchangeable cations were of a lower valency especially when it is a univalent cation (Carlson, 2004).

Conversely, most Bentonite deposits are non-swelling Bentonite (principally made up of calcium montmorillonite). Attempts have been made to convert calcium Bentonite to sodium Bentonite by treating them with sodium salts in order to exchange the calcium ions for sodium and obtain a bentonite with improved swelling capacity and viscosity (Karnland, 2006). There is also increasing demand for Bentonite in other areas such as cosmetics, pharmaceuticals etc. generally bentonites that are required for these applications are pure white Bentonite with a high montmorillonite content and whose exchangeable cations are least $60 \%$ univalent cations. 
Table 1. Sample Collection Points and Coordinates

\begin{tabular}{ccccc}
\hline Points & North & Easting & Elevation (m) & Weight (kg) \\
\hline 1. & $13^{0} 59^{1} 22.6^{11}$ & $0.09^{0} 51^{1} 32.2^{11}$ & 240 & 25 \\
2. & $13^{0} 59^{1} 22.6^{11}$ & $0.09^{0} 51^{1} 32.2^{11}$ & 235 & 25 \\
3. & $13^{0} 59^{1} 22.6^{11}$ & $0.09^{0} 51^{1} 32.2^{11}$ & 230 & 25 \\
\hline
\end{tabular}

However, most Bentonite deposits contain a significant quantity of non-clay mineral particles which constitute impurities. These often adversely affect their quality for eventual application. Thus, those bentonites need some processing or beneficiation to free them of the impurities, increase their montmorillonite content, and/or to improve their properties to an acceptable level prior to the desired applications (Odom, 2006).

Faya is located in Langtang South Local Government area of Plateau State, Nigeria. It is a Local Government Area in Plateau State, Nigeria; with its headquarters in Mabudi town. It has an area of $838 \mathrm{~km}^{2}$ and a population of 106,305 at the 2006 census. Plateau State is located in Nigeria's middle belt; with an area of 26,899 square kilometres, the State has an estimated population of about three million people (Alexander, 2005). It is located between latitude $80^{\circ} 24^{\prime} \mathrm{N}$ and longitude $80^{\circ} 32^{\prime}$ and $100^{\circ} 38^{\prime}$ east. Bare rocks are scattered across the grasslands, which cover the Plateau. (Alexander, 2005). Hence, the need to beneficiate Faya Clay for Drilling Mud Production, Using Froth Floatation and Jig Gravity Concentration Techniques toward oil drilling mud production.

\section{Materials and Method \\ 2.1 MATERIALS}

Twenty-five $(25 \mathrm{~kg})$ kilograms sample of Faya bentonite was collected each from three veins, with specification as shown in Table 1. The three samples were homogenized and crushed with laboratory crusher (Atico), and ground using laboratory ball mill, (model x 509 Shambavi impact), a facility of Mineral Engineering, Kaduna Polytechnic, Kaduna State, Nigeria. The crushed and ground sample was further sampled using conning and quartering in the laboratory to obtain about $5 \mathrm{~kg}$ head sample, a representative fraction of the ore from the three veins. $1 \mathrm{~kg}$ representative fraction of the ore was taken to the laboratory for ore compositional study while $4 \mathrm{~kg}$ was used for the bench work.

\subsection{Characterization of the Sample Collected}

The sample collected was subjected to the following characterization using X-ray fluorescence (XRF) spectroscopy and X-ray diffraction (XRD).

\subsubsection{Chemical Characterization of Faya Clay Sample}

The sample was pulverized, packed and labelled. $20 \mathrm{~g}$ of the prepared sample was weighed each into a sample cup. The cup and the content were carefully placed in their respective measuring position on the sample changer of the machine. The XRF analysis was carried out with an $\mathrm{x}$ MET 5100, model x Mds 26700 a facility of Mineral Resources Engineering Kaduna Polytechnic. Kaduna.

\subsubsection{Mineralogical Characterization of Faya Clay}

The XRD 6000 Shimadzu XRD instrument of Nigeria Geological Survey Agency (NGSA) Kaduna was used for this work. A representative fraction of the sample of Faya clay was ground to a fine powder of about $75 \mu \mathrm{m}$ $(75 \mu \mathrm{m} / 0.029 \mathrm{mesh})$. A standard (silicon standard) was $\tilde{\tilde{\tilde{a}}}$ lso ground to the same size. The powder was put into milled well on aluminium holder and press with glass slide to cause the powder to stick well. It was then labelled or marked. It was then introduced into the XRD machine to identity the electronic output. The calibration of the XRD machine was checked with silicon (Si) standard and the silicon standard peak adequately scanned, before starting the operation.

\subsubsection{Particle Size Analysis of Faya Clay}

Particle size Analysis of the sample of Faya clay was carried out using $1000 \mathrm{~g}$ of the sample which was pulverized and $800 \mathrm{~g}$ collected. The weighed sample was ground in a ball mill to $100 \%$ passing $500 \mu \mathrm{m}$ and set of sieves were arranged from the $500 \mu \mathrm{m}$ using $\sqrt{2}$ sieve selection factor. The arrangement was then placed on a pan with $200 \mathrm{~g}$ weighed sample on the topmost sieve $(500 \mu \mathrm{m})$ with a lid to cover. The arrangement was placed on top of an automated sieve shaker, model LM200LK3004 lawkim, a facility of Mineral Resources Engineering, Kaduna Polytechnic. The sample was shocked to about $100 \%$ passing $500 \mu \mathrm{m}$, and sieve fractions were collected and weighed accordingly. Finally, the weighed fractions were then used to prepare a spread sheet to examine particle size distribution and the $80 \%$ passing determined.

\subsection{CONCENTRATION OF FAYA CLAY}

The sample of Faya clay was beneficiated using two methods; Froth flotation and Gravity concentration.

\subsubsection{Froth Flotation Method}

The flotation of the sample of Faya clay, was carried out using a Denver froth flotation machine; model BJAE $1982 / 1$. The clay sample was finely ground to $-125+90 \mu \mathrm{m}$, $150 \mathrm{~g}$ of the ground ore was used to make slurry in the ration of 1:3. The slurry formed was conditioned for about 3 minutes. Condition was made favourable for adherence of desired mineral to air bubbles by addition of oleic acid, pine oil and starch while maintaining a $\mathrm{pH}$ of 9 by addition of controlled amount of $\mathrm{H}_{2} \mathrm{SO}_{4}$ and $\mathrm{Na}_{2} \mathrm{CO}_{3}$ as the modifiers. A rising current of air bubbles was created. Mineral laden froth was scooped. The products of froth flotation were dried and weighed.

\subsubsection{Gravity Concentration Method}

Gravity concentration of the sample of Faya clay was carried out using jigging, with a reliance jig machine, model 705710 UA.; $200 \mathrm{~g}$ of the ground sample was used to form slurry 
(ratio of solid to water maintained at 1:10). The Jig was rinsed properly with clean water to avoid contamination. The huth compartment of the jig was filed with water and the slurry fed in as appropriate. The overflow and underflow (spigot), were collected, allowed to settle for 24 hours decanted, dried and weighed.

\subsection{Chemical Analysis of the Product of CONCENTRATION}

The products obtained from the concentration exercise were analysed. The composition of $\mathrm{BaO}, \mathrm{SiO}_{2}, \mathrm{Fe}_{2} \mathrm{O}_{3}$, $\mathrm{Al}_{2} \mathrm{O}_{3}, \mathrm{CaO}$ and $\mathrm{K}_{2} \mathrm{O}$, in the concentrates and tailings of the two operations, were used to examine the efficiency of the concentration operations.

\subsection{Determination OF SpECIFIC GRAVITY}

The specific gravity of the head sample of Faya clay and the beneficiated products, were determined using Pycnometer bottle, weighing balance; Distilled water and Faya mineral samples. The following procedure was further followed; the mineral sample was weighed alone in air and recorded as Wa. The bottle was filled with distilled water and weighed alongside the sample and recorded as Ws. The mineral sample was then charged into the bottle from which it displaced an equal bulk of water. It was weighed and recorded as Ww. The specific gravity was calculated from the relationship.

$$
\text { Specific gravity }=\frac{W a}{W s-W w}
$$

\section{RESULTS AND DISCUSSION}

\subsection{Chemical Composition of Faya Clay}

Table 2 presents the result of chemical analysis of the head sample of Faya clay. The result indicated that the sample contains $16.6 \% \mathrm{Al}_{2} \mathrm{O}_{3}, 35.6 \% \mathrm{SiO}_{2}, 0.559 \% \mathrm{~K}_{2} 0,0.084 \%$ $\mathrm{CaO}, 6.133 \% \mathrm{Fe}_{2} \mathrm{O}_{3}, 0.912 \% \mathrm{Tio}_{2}$ and $38.7 \%$ Bao. Other compounds found in traces include $\mathrm{CuO}, \mathrm{Ag}_{2} \mathrm{O}, \mathrm{CeO}_{2}$ and $\mathrm{SO}_{3}$. Okorie et al., (2015), reported that most of Nigerian bentonitic clays are predominantly calcium / potassium based and require some measure of beneficiation to be effective for use as drilling mud. Also, impurities such as iron, in the form of hematite and silica reduces the specific gravity of the clay.

\subsection{XRD ANALYSIS OF THE FAYA CLAY}

Figure 1 present the XRD pattern of Faya Clay. It indicates the major diffraction peaks of the minerals in the Clay and reveals the major compounds found, their appearance in the ore and corresponding chemical formulae. The result shows that quartz is predominant in the sample with 61.7 $\%$ wt quartz $\left(\mathrm{SiO}_{2}\right)$. Other minerals found in the sample include $28.59 \%$ wt of dickite $\left(\mathrm{Al}_{2} \mathrm{Si}_{2} \mathrm{O}_{5}(\mathrm{OH})\right), 8.89 \% \mathrm{wt}$ goethite $\left(\mathrm{FeO}(\mathrm{OH})_{4}\right)$ and $0.83 \%$ wt muscovite (KO.92 $\mathrm{NaO}_{8}$ ) (Al1.86 FeO.O $\mathrm{TiO}_{3}$ ) (Si3.03 AlO.97) $0_{10}(\mathrm{OH}) 2$ at $2 \theta$. The high percent composition of silica indicated the need for some level of beneficiation of the clay for improved specific gravity, to make it suitable for oil and gas drilling mud application.

Table 2. Chemical Composition of the Head Sample of Faya Clay

\begin{tabular}{cccc}
\hline $\mathbf{S} / \mathbf{N}$ & Element (oxide) & PPM & Percentage Composition \\
\hline 1 & $\mathrm{AL}_{2} \mathrm{O}_{3}$ & 166000 & 16.6 \\
2 & $\mathrm{SiO}_{2}$ & 356000 & 35.6 \\
3 & $\mathrm{SO}_{3}$ & 5600 & 0.56 \\
4 & $\mathrm{~K}_{2} \mathrm{O}$ & 5590 & 0.559 \\
5 & $\mathrm{CaO}$ & 840 & 0.084 \\
6 & $\mathrm{TiO} 2$ & 9120 & 0.912 \\
7 & $\mathrm{MnO}_{2}$ & 510 & 0.051 \\
8 & $\mathrm{Fe}_{2} \mathrm{O}_{3}$ & 61330 & 6.133 \\
9 & $\mathrm{CuO}_{2}$ & 220 & 0.022 \\
10 & $\mathrm{Ag}_{2} \mathrm{O}$ & 7370 & 0.737 \\
11 & $\mathrm{BaO}$ & 387000 & 38.7 \\
12 & $\mathrm{CeO}_{2}$ & 200 & 0.02 \\
\hline
\end{tabular}

Table 3. Result of Sieve Analysis of Faya clay

\begin{tabular}{cccccc}
\hline Sieve Size $\boldsymbol{\mu m}$ & Weight $(\mathbf{g})$ & Weight $(\%)$ & $\begin{array}{c}\text { Normal } \\
\text { aperture }\end{array}$ & $\begin{array}{c}\text { \% Cumm. } \\
\text { Oversize }\end{array}$ & $\begin{array}{c}\text { \% Cumm. } \\
\text { Undersize }\end{array}$ \\
+500 & 0.198 & 0.10 & 500 & 0.10 & 99.9 \\
$-500+355$ & 10.692 & 5.40 & 355 & 5.50 & 94.5 \\
$-355+250$ & 18.810 & 9.50 & 250 & 15.0 & 85.0 \\
$-250+180$ & 33.660 & 17.0 & 180 & 32.0 & 68.0 \\
$-180+125$ & 35.640 & 18.0 & 125 & 50.0 & 50.0 \\
$-125+90$ & 19.801 & 10.0 & 90 & 60.0 & 40.0 \\
$-90+63$ & 27.720 & 14.0 & 63 & 74.0 & 26.0 \\
Pan & 51.480 & 26.0 & Pan & 100 & 00 \\
\hline
\end{tabular}




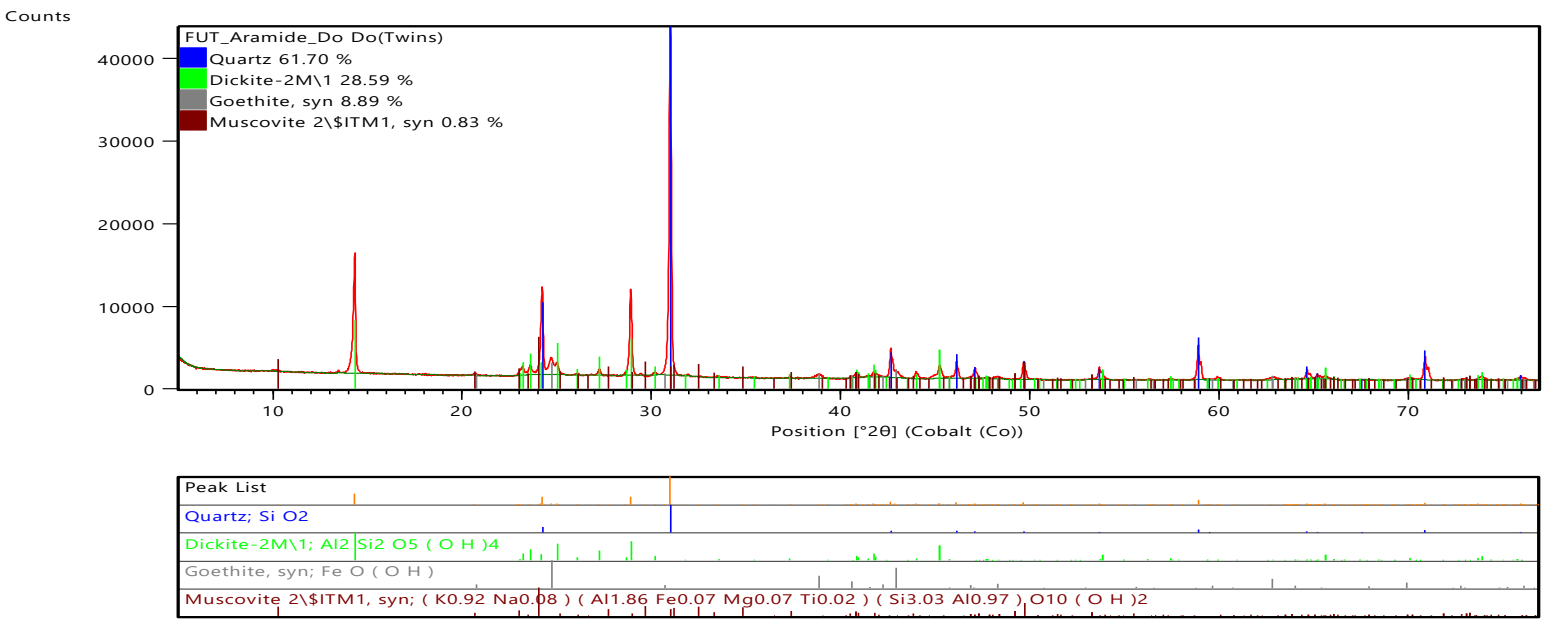

Fig. 1: XRD Pattern of Faya Clay

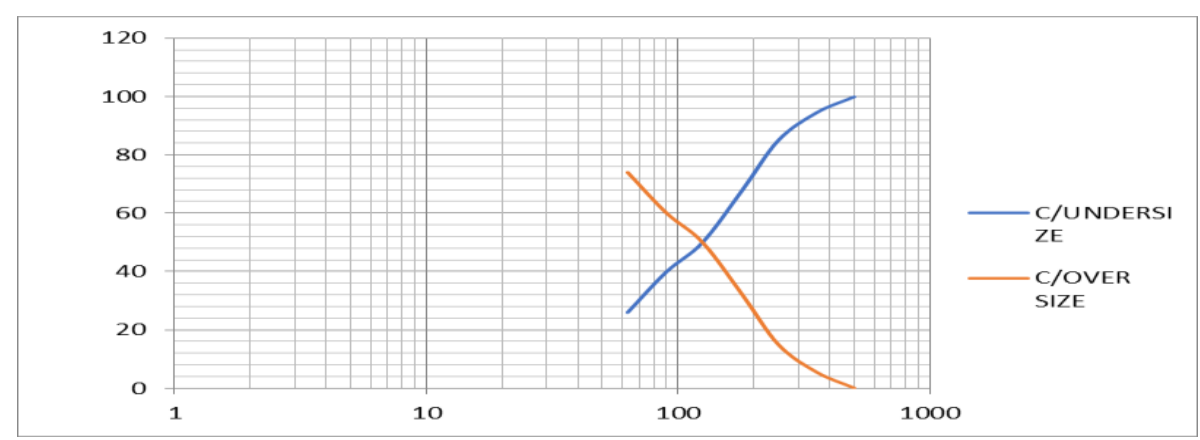

Fig. 2: PSD Line for cumulative Weight \% Undersize and Oversize against Sieve Size

Table 4. Result of Analysis of Products of Concentration Operation

\begin{tabular}{|c|c|c|c|c|}
\hline \multirow{3}{*}{$\begin{array}{c}\text { Chemical } \\
\text { Composition }\end{array}$} & \multicolumn{4}{|c|}{ \% Composition } \\
\hline & \multicolumn{2}{|c|}{ Concentrate } & \multicolumn{2}{|c|}{ Tailings } \\
\hline & Floatation & Jigging & Floatation & Jigging \\
\hline $\mathrm{Al}_{2} \mathrm{O}_{3}$ & 18.60 & 19.89 & 15.90 & 11.30 \\
\hline $\mathrm{SiO}_{2}$ & 23.00 & 34.92 & 53.00 & 49.00 \\
\hline $\mathrm{SO}_{3}$ & 0.510 & 0.530 & 2,525 & 2.460 \\
\hline $\mathrm{K}_{2} \mathrm{O}$ & 0.678 & 0.812 & 0.120 & 0.300 \\
\hline $\mathrm{CaO}$ & 1.122 & 1.092 & 0.440 & 0.800 \\
\hline $\mathrm{TiO}_{2}$ & 0.990 & 1.903 & 0.820 & 0.900 \\
\hline $\mathrm{MnO}$ & 0.039 & 1.046 & 0.063 & 0.037 \\
\hline $\mathrm{Fe}_{2} \mathrm{O}_{3}$ & 2.050 & 5.590 & 16.80 & 18.50 \\
\hline $\mathrm{CuO}$ & 0.023 & 0.026 & 0.001 & 0.003 \\
\hline $\mathrm{Ag}_{2} \mathrm{O}$ & 0.760 & 1.920 & 0.901 & 0.939 \\
\hline $\mathrm{B}_{9} \mathrm{O}$ & 52.20 & 47.5 & 9.300 & 15.80 \\
\hline $\mathrm{CeO}_{2}$ & 0.008 & 0.530 & 0.010 & 0.020 \\
\hline $\mathrm{Eu}_{2} \mathrm{O}_{3}$ & 0.020 & 0.020 & 0.020 & 0.015 \\
\hline
\end{tabular}

Table 5. Metallurgical Accounting Parameters for the Result obtained from Analysis of Products of Concentration of Faya Clay

\begin{tabular}{ccccccccc}
\hline \multirow{2}{*}{$\begin{array}{c}\text { Concentration } \\
\text { method (s) }\end{array}$} & $\begin{array}{c}\mathbf{W t} \\
\mathbf{( g )}\end{array}$ & $\begin{array}{c}\text { Assay } \\
\mathbf{( \% )}\end{array}$ & $\begin{array}{c}\text { Recovery } \\
\mathbf{( \% )}\end{array}$ & $\begin{array}{c}\text { Ratio of } \\
\text { Concentrate }\end{array}$ & $\begin{array}{c}\text { Enrichment } \\
\text { Ration }\end{array}$ & $\begin{array}{c}\text { Wt } \\
\mathbf{( g )}\end{array}$ & $\begin{array}{c}\text { Assay } \\
(\%)\end{array}$ & $\begin{array}{c}\text { Recovery } \\
(\%)\end{array}$ \\
\hline Froth flotation & 136 & 52.2 & 97.2 & 1.4 & 1.4 & 41 & 3.9 & 2.9 \\
Jigging & 132 & 47.5 & 90.96 & 0.7 & 0.7 & 46 & 13.5 & 9.2 \\
\hline
\end{tabular}




\subsection{SIZE ANALYSIS}

Table 3 show the result of sieve size analysis while Figure 2 show the particle size distribution (psd) line for both cumulative weight percent undersize and oversize verse sieve size. The economic liberation size was found to be $125 \mu \mathrm{m}$, indicated by the intersection point of the lines.

Table 4 present the result of the chemical analysis of the concentrates and tailings of froth flotation and jigging method of concentration, at economic liberation size of $125 \mathrm{um}$. The result reveal that there is an improvement in the $\mathrm{BaO}$ composition from $38.7 \%$ in the head sample to $52.2 \% \mathrm{BaO}$ in the concentrate of froth flotation, and $47.5 \%$ $\mathrm{BaO}$ for jigging operation. However, silica composition reduced from $35.6 \% \mathrm{SiO}_{2}$ in the head sample to $23 \%$ and $34.92 \% \mathrm{SiO}_{2}$ for froth flotation and jigging method respectively. Similarly, in both cases $\mathrm{Fe}_{2} \mathrm{O}_{3}$ composition decreased to 2.050 and $5.59 \%$. Other compounds that witness increase in percent composition are; $\mathrm{K}_{2} \mathrm{O}, \mathrm{Al}_{2} \mathrm{O}_{3}$, and $\mathrm{CaO}$.

The percent composition of $\mathrm{SiO}_{2}$, and $\mathrm{Fe}_{2} \mathrm{O}_{3}$ increase in the tailing for both methods, and a drop in percent composition of $\mathrm{BaO}, \mathrm{Al}_{2} \mathrm{O}_{3}$ and $\mathrm{K}_{2} \mathrm{O}$ and $\mathrm{CaO}$. The result shows an indication of upgrading of the as mined Faya clay, since there is a considerable increase in the desired compounds and decrease in undesirable components in the concentrate.

Table 5 present the result of metallurgical accounting for the products of concentration of Faya Clay. The result revealed that out of $180 \mathrm{~g}$ of feed material to jigging operation, $132 \mathrm{~g}$ was recovered as concentrate and $46 \mathrm{~g}$ as tailings while, $136 \mathrm{~g}$ was recovered as concentrate and 41 $\mathrm{g}$ - as tailings in the case of froth flotation. However, the result shows that the concentrate of flotation assayed $52.2 \% \mathrm{BaO}$, Implying a recovery of $97.2 \%$, with enrichment ratio of 1.4 and ratio of concentration of 1.4 . Similarly, the concentrate of the jigging assayed $47.5 \%$ $\mathrm{BaO}$ showing recovery of $90.90 \%$ and enrichment of 0.7 and ratio of concentration of 0.7 .

Table 6, present the result of specific gravity test, carried out on the as mined Clay and the concentrates of jigging and froth flotation methods of concentration. The result revealed that froth flotation improved the specific gravity of the as mined Clay from 3.3 - 4.3, while jigging improved from $3.3-4.05$.

Table 6. Result of Specific Gravity Test on Head Sample and Processed Products.

\begin{tabular}{cc}
\hline Products & Specific gravity \\
\hline Head sample & 3.30 \\
Flotation & 4.31 \\
Jigging & 4.05 \\
\hline
\end{tabular}

\section{Conclusion}

The research focused on the comparative study for upgrading of Faya clay in Plateau State, Nigeria. Conclusions were drawn were that the chemical composition of the crude bentonite was found out to be $16.6 \% \mathrm{Al}_{2} \mathrm{O}_{3}, 35.6 \% \mathrm{SiO}_{2}, 0.559 \% \mathrm{~K}_{2} \mathrm{O}, 0.084 \% \mathrm{CaO}, 6.133 \%$
$\mathrm{Fe}_{2} \mathrm{O}_{3}, 0.91 \% \mathrm{TiO}_{2}$ and $38.7 \% \mathrm{BaO}$; and the dominant elements in the clay are oxygen with average weight composition of $43.75 \%$ wt at $60 \mu \mathrm{m}$ and $45.78 \%$ wt at $6 \mu \mathrm{m}$ and silicon with $21.24 \%$ wt at $60 \mu \mathrm{m}$ and $27.58 \%$ wt at $6 \mu \mathrm{m}$.

Also, Froth flotation method is more efficient for the beneficiation of Faya clay as it improves the $\mathrm{BaO}$ composition of the clay from $38.7 \%$ to $52.2 \%$, with a recovery of $97.2 \%$ and an enrichment and ratio of concentration of 1.4 when compared with the jigging method, which improved $\mathrm{BaO}$ composition from $38.7 \%$ in the crude ore to $47.5 \%$, with a recovery of $90.96 \%$ and an enrichment and ratio of concentration of 0.7. Froth floatation improved the specific gravity of the clay from 3.3 to 4.31 while jigging improved the specific gravity from 3.3 to 4. 05. Hence, Froth flotation method is preferred ahead of jigging in upgrading Faya bentonite to be use as an oil drilling mud.

\section{REFERENCE}

Abdullahi, S.L and Audu, A.A (2015). Comparative Analysis on Chemical Composition of Bentonite Clays obtained from Ashaka and Tango Deposits in Gombe State, Nigeria. ChemSearch Journal. 8(2): 3540.

Alabi, O.O., Yaro, S.A., Dungka, G.T., Asuke, F. and Dauda, E.T. (2015). Determination of Work Index of Gyel-Bukuru Columbite Ore in Plateau State, Nigeria. Journal of Minerals and Materials Characterization and Engineering, 3:194-203.

Alexander, M. J (2005). "Soil fertility management strategies on the Jos Plateau: the need for integrating 'empirical' and 'scientific' knowledge in agricultural development". Geographical Journal. 171 (2): 112-124

Carlson, L. (2004). Bentonite mineralogy. Part 1: Methods of investigations - a literature review; Part 2: Mineralogical research of selected bentonites. Posiva Oy Working Report 1 (1); 2 - 4.

Gaudin A.M. (1999). Principle of Mineral Dressing, McGraw-Hill, New York 2 (1) 17.

Gbadamosi, Y. E., Alabi, O. O., Borode J. O. (2021). Evaluating the Potentials of Liberation Size Determination in Anka (Zamfara State, Nigeria) Manganese Ore and its Communition Tendency using Bond Index Technique. Journal of Materials Science Research and Reviews, 8(1):7-18.

Geological Survey of Nigeria (2010); The geology of part of South Western Nigeria Bentonite, Wyoming Geological Survey Bulletin 26 (31). 1- 40.

Gupta C.K. (2006). Mineral Processing Design and Operation, An introduction; Elsevier, ISBN13978 -0-444-5.63 (1) 6 - 7

Karnland, O., Olsson, S. and Nilsson, U. (2006). Mineralogy and sealing properties of various bentonites and smectite-rich clay material. $S K B$ Technical Report TR-06-30.1(1) 12

Klima, M. (2010). Mineral Processing. The Pennsylvania State University, 115 Hosler Building, University Park, PA 16802-5000, USA. 1(1) 3.

Odom, I. E. (2006). "Smectite clay Minerals: Properties and Uses". Philosophical Transactions of the Royal Society A: Mathematical, Physical and Engineering Sciences 311 (1517): 391. Bibcode:1984RSPTA.311..391O. doi:10.1098/rsta.1984.0036. JSTOR 37332

Robertson, R.H.S. (1986). Fuller's Earth. A History of calcium montmorillonite. Volturna, Press, U.K., ISBN 0-85606-070-4, 1 (1) 7- 12

Theng, B.K.G. (2002). Formation and Properties of Clay Polymer Complexes. Developments in Soil Science 9. Elsevier, Amsterdam, ISBN 0-444-41706-0 9(1); 6

Wills, B.A. \& Napier-Munn, T.Y. (2006); “Wills Mineral Processing Technology." An introduction to the practical aspects of ores treatment and mineral recovery, $7^{\text {th }}$ edition; Elsevier Publishers, 7 (1); 108-115. 